\title{
PRILOG ANALIZI ČIMBENIKA ODABIRA MJESTA SEKUNDARNOG STANOVANJA: PRIMJER NASELJA OKRUG GORNJI NA OTOKU ČIOVU
}

\author{
Krešimir Peračković, Geran-Marko Miletić i Dora Mrčela
}

Institut društvenih znanosti Ivo Pilar Trg Marka Marulića 19, 10000 Zagreb e-mail: kreso@pilar.hr

\begin{abstract}
Sažetak
U radu se najprije prikazuju određena teorijska polazišta o čimbenicima odabira mjesta sekundarnog stanovanja od kojih se adekvatnim pokazao Opačićev koncept dviju skupina faktora privlačnosti: rekreacijsko - atrakcijska osnova receptivnog vikendaškog područja i ostali resursi. Polazeći od tog koncepta, uz spoznaje o lokalnim specifičnostima dobivenim u prethodnom kvalitativnom istraživanju na lokacijama u samom Okrugu, kreiran je istraživački instrumentarij s dva glavna indikatora: prirodne ugodnosti i situacijske okolnosti koji su operacionalizirani u nekoliko varijabli koje su ispitanici procjenjivali. Ukratko je prikazan i razvoj Okruga od razdoblja ruralne izolacije do današnje poželjne destinacije za sekundarno stanovanje uz kraći prikaz faza razvoja sekundarnog stanovanja. Glavni cilj empirijskog dijela rada jest istražiti koje okolnosti odnosno specifični motivi prevladavaju pri izboru Okruga te u kojoj su mjeri utjecali na odabir ove lokacije za mjesto sekundarnog stanovanja. Bit će prikazani i podaci o osnovnim obilježjima sekundarnog stanovanja u Okrugu koji su u analizi ujedno i nezavisne varijable. $U$ analizi će biti koristeni podaci prikupljeni anketnim istraživanjem provedenim u Okrugu Gornjem u proljeće i ljeto 2016. na probabilističkom višeetapno stratificiranom uzorku vikendaša. Od rezultata, najvažniji su oni koji pokazuju da su prirodne ugodnosti znatno češće od situacijskih okolnosti utjecale na odluku o odabiru Okruga Gornjeg za mjesto sekundarnog stanovanja. Povoljna klima, čisto more, i blizina plaže tri su najvažnija čimbenika, dok su kao tri najmanje važna čimbenika povoljna cijena nekretnine / zemljišta, zavičajna povezanost te očekivani porast cijena nekretnine.
\end{abstract}

Ključne riječi: Čiovo, Okrug Gornji, sekundarno stanovanje, vikendaštvo

\section{UVOD ${ }^{1}$}

Iako je sekundarno stanovanje u Hrvatskoj kao društveni i prostorni fenomen imalo svoj razvojni zamah već prije gotovo pola stoljeća, temeljitija istraživanja i domaći znanstveni radovi o toj temi pojavljuju se tek unazad 20-ak godina. Sam pojam podrazumijeva stanovanje koja se realizira $u$ drugom stanu, drugoj kucii, ne u mjestu stalnog

1 Ovaj rad financirala je Hrvatska zaklada za znanost projektom UIP-11-2013-1875. 
boravka i ne za stalno, nego za privremeno stanovanje (Čaldarović, 1989:105). Ta potraga za drugim prostorom (Miletić, 2011) najprije uključuje izbor neke konkretne lokacije različite od primarnog stanovanja s obzirom na neka od klimatskih, prirodno-geografskih i socio-prostornih (Opačić, 2011) a ponekad i socio-kulturnih obilježja, osim ako se radilo o nekoj naslijeđenoj nekretnini u zavičaju predaka. Stoga sekundarno stanovanje u ovom smislu ne znači samo puku činjenicu posjedovanja druge nekretnine (primjerice drugi stan ili kuća u istom mjestu ne ulazi u tu kategoriju prema navedenoj definiciji), već znači i izbor druge ili drugačije lokacije, pa je to kao što naglašava Čaldarović upravo neprimarno stanovanje koje nije u mjestu stalnog boravka te ono ima prije svega $\mathrm{i}$ obilježje privremenosti. U tim ranijim radovima pojavljuje se i pojam engl. second home tj. drugi dom, drugi stan, druga kuća ili druga stambena scena (Mišetić, 2006), a u novije se vrijeme spominje i pojam višestruki dom (engl. multiple home) (Barke, 2008; Paris, 2009), jer postmoderna društva karakteriziraju brojne prakse horizontalnih i mrežnih modela stanovanja pa se govori čak i o heterotopičnoj praksi (Halfacree, 2011). ${ }^{2}$

U svojoj, danas, već klasičnoj analizi funkcija izvangradskih sekundarnih rezidencija, Coppock (1977) ističe kako je upravo odabir lokacije i njezinih obilježja u pozadini glavnih motiva za posjedovanje druge kuće, jer su to lokacije uglavnom izvan grada te označavaju zapravo bijeg od pritiska urbanoga načina života, odnosno kontraurbanizaciju i podrazumijevaju sudjelovanje u nekim aktivnostima koje su povezane s ruralnim resursima, želju za obnovom ili održavanjem veza s mjestom podrijetla, osiguravanje mjesta za provodenje praznika, svojevrsnu investiciju, potvrdu statusa i osiguravanje mjesta za život u mirovini (Coppock, 1977:9, u: Miletić i Mišetić, 2006:62). U pregledu novije literature Miletić i Mišetić prikazuju također i koncept životnog stila koji nije moguće realizirati u primarnoj rezidenciji te se može prakticirati u različitom mjestu od primarnog obitavališta, što postaje jedan od važnijih pokretača želje za sekundarnim stanovanjem, a to je također povezano i sa sve većom ulogom putovanja, slobodnog vremena, turizma i mobilnosti u suvremenom svijetu. Hall i Müller naglašavaju upravo tu važnost premještanja ili inverzije od svakodnevnog urbanog života, polazeći od Chaplinove teze o bijegu koji osigurava ravnotežu u životu (Chaplin, 1999), kao i od Kalternbornovog isticanja potrage za autentičnim ili stvarnim svijetom (Kaltenborn, 1998). No ono što je osobito važno i za ovaj rad koji je fokusiran na izbor konkretne lokacije, takvo posjedovanje i korištenje druge kuće oni razmatraju kao ritualnu praksu povratka na isto mjesto čime ono postaje mjesto redovitog ponavljanja istih aktivnosti. ${ }^{3} \mathrm{U}$ navođenju razloga za posjedovanje stana za odmor ne smije se zanemariti ni činjenica da na odluku o stjecanju sekundarnog stana te osobito i o odabiru specifične lokacije utječu i strukturalni čimbenici poput povećanja raspoloživih

\footnotetext{
2 U stranoj literaturi izraz second home doslovno znači drugi dom, a domoći autori za isti pojam koriste više izraza: sekundarno stanovanje, stanovi i kuće za odmor, vikendice itd. Tako i u ovom radu koristimo više izraza za taj isti pojam kao npr.: sekundarni stan, dom, kuća ili stambena jedinica.

3 Baveći se također motivima, Norris i Winston izdvajaju slične, tri osnovne grupe razloga za posjedovanje sekundarnog stana, a to su prema njihovom mišljenju: bijeg, investiranje i umirovljenje (Norris i Winston, 2010). Osim tih u literaturi se često kao motiv spominje i kompenzacija, pri čemu ta interpretacija sekundarno stanovanje vidi kao pokušaj nadoknađivanja nedostataka stanovanja na prvoj adresi (Coppock,
} 
prihoda kućanstva, fleksibilnijeg radnog vremena, unaprjeđenje prometne povezanosti, ali i sve prisutnija kultura konzumerizma (Paris, 2009).

U ovom radu nećemo ulaziti u temeljitiju analizu samog fenomena sekundarnog stanovanja, ${ }^{4}$ kao ni u istraživanje same motivacije već ćemo se fokusirati upravo na istraživanje čimbenika za izbor sekundarnog stana na jednoj konkretnoj lokaciji u Hrvatskoj, u mjestu Okrug Gornji na otoku Čiovu, jednom od onih mjesta u kojima se dogodio veliki porast broja stanova za odmor u zadnjem međupopisnom razdoblju. ${ }^{5} \mathrm{U}$ radu ćemo najprije prikazati neka teorijska polazišta o čimbenicima odabira mjesta sekundarnog stanovanja kao i konceptualnu razliku između odabira mjesta i same motivacije za sekundarnim stanovanjem, potom ćemo se osvrnuti na sam razvoj Okruga ${ }^{6}$ od razdoblja ruralne izolacije do današnje poželjne destinacije za sekundarno stanovanje uz kraći prikaz faza razvoja sekundarnog stanovanja u ovom otočkom naselju. Zatim ćemo prikazati rezultate empirijskog istraživanja o čimbenicima odabira tog mjesta kao poželjne lokacije za sekundarno stanovanje te kroz analizu pokušati dati odgovor na pitanje zašto odabrati Okrug za svoj drugi dom.

\section{2. ČIMBENICI ODABIRA MJESTA SEKUNDARNOG STANOVANJA: TEORIJSKO-KONCEPTUALNI OKVIR}

Već iz ovih osnovnih uvida o elementarnoj motivaciji za sekundarnim stanovanjem, istraživači su uočili i ključno obilježje tog drugog doma, a to je povremenost upotrebe, najčešće za odmor ili rekreaciju. Prema tome, možemo uočiti da je (pod pretpostavkom

1977). Pojedini autori koji sekundarno stanovanje dovode u kontekst teorije životnih stilova, stan za odmor percipiraju kao okosnicu heterolokanog (Halfacree, 2012) ili pak dokoličarskog (Huijbens, 2012) životnog stila. Ne ulazeći u temeljitiji pregled literature o motivima za sekundarno stanovanje, što je zasebna tema, potrebno je možda izdvojiti još neke iz kojih se mogu razlučiti i čimbenici odabira same lokacije: ravnoteža između životne rutine i novotarija, povratak prirodi, potraga za identitetom, sigurnost, elitizam, bijeg, djeca, posao, ekonomski isplativiji odmor i dr. (Quinn, 2004).

$4 \mathrm{U}$ knjizi U potrazi za drugim prostorom - Sociologijski aspekti sekundarnog stanovanja u Hrvatskoj, prikazane su temeljito suvremene sociologijske teorije o sekundarnom stanovanju, a četvrto je poglavlje fokusirano na evoluciju sekundarnog stanovanja u Hrvatskoj. Najprije je prikazana kratka povijest prisutnosti stanova za odmor u Hrvatskoj, od skromnih početaka prije II. svjetskog rata, potom kroz prva desetljeće socijalizma u kojima se očitovala društvena nepoželjnost stanova za odmor, zatim u razdoblju ekspanzije sekundarnog stanovanja od 1971. do 1991. godine i na kraju u razdoblju prijelaza iz 20. u 21. stoljeće. U drugom su dijelu ovog poglavlja prikazane osnovne značajke te prostorni razmještaj stanova za odmor u Hrvatskoj prema Popisu iz 2001. godine prema kategorijama opremljenosti i karakteristika stanova za odmor te razmještaja stanova za odmor. Na kraju se raspravlja o koristima i štetama od širenja sekundarnog stanovanja u Hrvatskoj te definira aktere i njihovu motivaciju za sekundarno stanovanje u Hrvatskoj (Miletić, 2011). 5 Prema podacima Popisa stanovništva u 2011. na području općine Okrug 2011. godine evidentirano je 2047 stanova za odmor te 1284 nastanjena stana, odnosno oko 159 stanova za odmor na 100 stalno nastanjenih stanova (Državni zavod za statistiku, 2011). Pritom je broj stanova za odmor u odnosu na 2001. godinu porastao za gotovo 33\% (Državni zavod za statistiku, 2001).

6 Današnja općina Okrug sastoji od Okruga Gornjeg i Okruga Donjeg, a ovo istraživanje je provedeno u Okrugu Gornjem. Zbog čestih ponavljanja, nadalje će se navoditi samo naziv Okrug, pri čemu će se podrazumijevati Okrug Gornji. 
financijskih mogućnosti) i u pozadini odabira konkretne lokacije za sekundarno stanovanje, bez obzira je li riječ o kupnji već gotove nekretnine ili o izgradnji na kupljenom zemljištu, upravo različitost prostora u odnosu na primarni, iz čega pak proizlazi i različita funkcija odnosno svrha drugog stana (budući da je u većini slučajeva riječ o stanu za odmor), kao i načina djelovanja odnosno aktivnosti koje pojedinci prakticiraju za vrijeme boravka u sekundarnom stanu i drugačijem prostoru. I u ranijim domaćim istraživanjima sekundarnog stanovanja kao bitno obilježje fenomena istaknuta je upravo potraga za drugim i drugačijim prostorom. Rogić (1990) tako smatra da je sekundarno stanovanje, između ostalog, i svojevrsni pokušaj negacije industrijskoga grada, a na tom tragu je i Čaldarović (1989) kad navodi da je dio sekundarnog stanovanja zasigurno motivirano bijegom iz betonske džungle i(li) nekomfornog gradskog stana. Rogić zaključuje kako poticaje za sekundarno stanovanje na drugačijoj lokaciji od primarne možemo razvrstati u četiri kategorije: 1) kao opreku industrijskoj svakodnevici; 2) kao nostalgiju koja teži rekonstrukciji zavičajnog identiteta; 3) kao autorsku negaciju industrijskog grada i 4) kao alternativnu štednju (Rogić, 2006). ${ }^{7}$ Stoga možemo reći da su čimbenici odabira lokacije latentno prisutni već i u samoj motivaciji za sekundarnim stanovanjem, budući da su obilježja toga mjesta najčešće suprotna onima u mjestu primarnog stanovanja što artikulira i djeluje na samu motivaciju.

Međutim, domaća literatura koja je primarno fokusirana na istraživanje čimbenika odnosno okolnosti koje su utjecale na odabir lokacije za gradnjom ili kupnjom sekundarnog stana vrlo je oskudna, i ta se tema uglavnom spominjala u sklopu drugih tema o sekundarnom stanovanju. Stoga ćemo prikazati neke strane autore koji su ovu temu obrađivali u svojim istraživanjima. Tako npr. Hall i Muller (2004) ističu da lokacija sekundarnog stana ne ovisi samo o vremenu putovanja između prve i druge adrese, već i o razini ugodnosti koju neka lokacija nudi kao i o troškovima stjecanja i održavanja nekretnine. Uz ove kako ih Hall i Muller (2004) nazivaju primarno ekonomske čimbenike, kao razloge smještanja stana za odmor na određenoj lokaciji identificirali su još i zavičajne (Jaakson, 1986; Muller, 2004; Rogić, 1990) i prijateljske veze (Pitkänen, 2008) te odnos lokalne vlasti prema prostornom razvoju (Gallent, 2007). U nedostatku socioloških teorijskih koncepata o čimbenicima odabira lokacije za sekundarno stanovanje, kao jedan od mogućih pristupa može poslužiti Opačićev model push-pull koji integrira s jedne strane motive za sekundarno stanovanje koje naziva pokretački faktori vikendaštva (faktori potražnje) i čimbenike odabira mjesta sekundarnog stanovanja koje pak naziva faktori privlačnosti receptivnoga vikendaškog područja (faktori ponude) koji značajno utječu na povećanje potražnje za sekundarnim stanovanjem (Opačić, 2011).

7 U svojoj analizi razvoja sekundarnog stanovanja u Hrvatskoj, Rogić promatra razdoblje od 1945. do 2005. s posebnim osvrtom na socijalističko i na tranzicijsko razdoblje. Budući da se sekundarno stanovanje intenzivnije pojavljuje u doba socijalističke modernizacije i industrijalizacije, Rogić motivaciju za potragom drugačijeg prostora u tom vremenu vidi upravo kao opreku industrijskom prostoru i industrijskom gradu (Rogić, 2006).

8 I Opačić također ističe kako adekvatnog pojma koji bi jednom riječju obuhvatio fenomen sekundarnoga rekreacijskog stanovanja u rječnicima hrvatskoga jezika nema, pa drži se da bi pojam „vikendaštvo” mogao 
Opačić smatra kako se, slično kao u turizmu, i u vikendaštvu mogu razlikovati te dvije osnovne skupine faktora koji utječu na njegov postanak i razvoj: a) pokretački faktori (push faktori, faktori potražnje) te b) faktori privlačnosti (pull faktori, faktori ponude) receptivnoga vikendaškog područja. Skupinu pokretačkih faktora dijeli na objektivne (neovisne od ponašanja pojedinca) i subjektivne faktore (motivacija za posjedovanje vikendice). Skupinu faktora privlačnosti sekundarnoga stanovanja dijeli također na dvije podskupine: rekreacijsku atrakcijsku osnovu receptivnoga područja te ostale resurse receptivnoga područja. Budući da se obje te podskupine faktora privlačnosti odnose na elemente ponude receptivnog vikendaškog područja, Opačić zaključuje da navedene grupe faktora utječu na izbor lokacije vikendice pošto je odluka o stjecanju vikendice već donesena, pa ih se može poistovjetiti s lokacijskim faktorima vikendaštva (Opačić, 2011: 184). Drugim riječima, ti lokacijski faktori su važan čimbenik odabira mjesta, nakon što je netko donio odluku i spreman je na kupnju ili gradnju vikendice, a još ne zna gdje. Rekreacijsku atrakcijsku osnovu dijeli na prirodne pogodnosti tj. atrakcije (npr. geomorfološka, klimatska, hidrografska, vegetacijska i faunistička obilježja te blizina zaštićenih područja) i društvene (antropogene) atrakcije (npr. kulturno-povijesna baština, kulturne i vjerske ustanove, manifestacije, kultura života i rada te turistička / rekreacijska „suprastruktura”). U ostale resurse receptivnog područja Opačić ubraja kvalitetu i očuvanost okoliša, prometno-geografski položaj i turističko-geografski položaj, broj ostalih pretendenata na rekreacijske zone, prometnu dostupnost i lokalnu povezanost, razvijenost komunalne infrastrukture, ukupnu uređenost, opskrbljenost uslugama, stav prema vikendašima u svim strukturama lokalne zajednice, situaciju na lokalnom tržištu nekretnina, tretman vikendaštva u prostorno-planskoj regulativi, političku i pravnu stabilnost te osobnu sigurnost (Opačić, 2011:185).

Prije svega, ovom Opačićevom modelu treba pristupiti kritički jer primjerice u ostale resurse ubraja čitav niz različitih okolnosti koje bi se mogle svrstati u barem nekoliko zasebnih kategorija (geografske, turističke, prometne, komunalne, tržišne itd). Stoga, od njegovog modela možemo eventualno zadržati pojam faktora privlačnosti receptivnog vikendaškog područja, no nužno ga je rekonceptualizirati u dva osnovna indikatora pogodna za daljnju operacionalizaciju u varijable. Cilj je empirijskog dijela rada istražiti koje su to bile okolnosti odnosno specifični motivi odabira Okruga te u kojoj su mjeri utjecali na odabir te lokacije za gradnju ili kupnju sekundarnog stana. Te okolnosti, sukladno Opačićevom konceptu koji sadrži dvije navedene skupine faktora privlačnosti (rekreacijsko-atrakcijsku osnovu receptivnoga područja i ostale resurse) uvažavajući specifičnosti lokacije i spoznaje dobivene u prethodnom kvalitativnom istraživanju (Miletić i sur., 2016) o čemu će biti više riječi u narednom poglavlju, grupirali smo

kvalitetno nadomjestiti taj manjak jer je razumljiv i jasan. Pod pojmom „vikendaštvo” razumijeva se fenomen vikendica (stambenih jedinica za odmor i rekreaciju), tj. fenomen sekundarnoga stanovanja. Može označivati vikendice kao raširenu pojavu te organiziranu djelatnost / aktivnost vikendaša, odnosno ukupnost svih pojava i procesa povezanih s pojmovima "vikendica”, „objekt za odmor i rekreaciju”, „drugi dom” te „sekundarno (povremeno) stanovanje (Opačić, 2011:198). 
kroz dva glavna indikatora koja će biti operacionalizirana u nekoliko varijabli koje su ispitanici procjenjivali: a) prirodne ugodnosti (npr. čisto more, mnoštvo zelenila i šuma, nezagađeni okoliš, blizina plaža, ljepota prirodnog krajolika, povoljna klima); b) situacijske okolnosti (npr. sređeni imovinsko-pravni odnosi i sigurnost kupnje, blizina stalne adrese stanovanja, povoljna cijena nekretnine / zemljišta, podrijetlo (osobno ili člana kućanstva) iz ovoga kraja, preporuka prijatelja i očekivani porast cijena nekretnine). Prije prikaza rezultata istraživanja, ukratko ćemo se osvrnuti na razvoj Okruga i identificirati čimbenike koji su s vremenom postali rekreacijsko-atrakcijska osnova Okruga kao receptivnog područja sekundarnog stanovanja.

\section{OSVRT NA RAZVOJ OKRUGA: OD RURALNE IZOLACIJE DO POŽELJNE DESTINACIJE ZA SEKUNDARNO STANOVANJE}

Predmet analize ove studije, naselje Okrug Gornji, dio je Općine Okrug, koja se sastoji od dva naselja (drugo je Okrug Donji). Općina prema Popisu 2011. broji 3349 stanovnika te tako spada u kategoriju hrvatskih općina srednje veličine. Današnja općina Okrug je kroz povijest najčešće bila pod jurisdikcijom grada Trogira, a najstariji pisani dokument $\mathrm{u}$ kojem se spominje naselje Okrug datira iz 1228. godine. U kontekstu problema suvremene gradnje u Okrugu gornjem, zanimljivo je da trogirski kroničar Andreis (17. st.) navodi kako je Statutom grada Trogira na cijelom otoku Čiovu bila zabranjena izgradnja koja je bila na snazi sve do 1416. godine kada je gradnja dopuštena pustinjacima i gubavcima (Andreis, 1977). Dolaskom mletačke vlasti 1420. i zbog čestih turskih napada, mletačka vlast 1451. dopušta stanovnicima dalmatinskog kopna naseljavanje na obližnje otoke, a mletački je senat na molbu trogirskih građana ukinuo prijašnju zabranu iz 1467. i dopustio da se na susjednoj čiovskoj obali može stanovati te graditi kuće. Zbog navala Turaka, od 15. stoljeća broj se stanovnika Čiova povećavao doseljavanjem izbjeglica s kopna, a tijekom 17. i 18. stoljeća trogirsko plemstvo gradi svoje ljetnikovce na otoku pa možemo reci da je već od tada mjesto atraktivno upravo za sekundarno stanovanje. ${ }^{9}$ Okrug je administrativno odvojen od grada Trogira 1997. godine kada postaje samostalna općina. Glavninu gospodarstva do prije 30-ak godine činili su poljodjelstvo (maslina, vinova loza, smokva, bademi, rogač, agrumi, ljekovito bilje) te ribolov, a mnogi su muški stanovnici nalazili posao i u obližnjem brodogradilištu (Radić, 2007). No, zbog blage klime, bujne mediteranske vegetacije i sigurnih luka Okrug se $s$ vremenom sve više okreće turizmu. ${ }^{10}$

\footnotetext{
9 Iako je nedovoljno poznato, Okrug ima vrlo bogatu kulturnu baštinu koju čine brojne crkve i crkvice, ljetnikovci i kaštele od kojih su najvažniji: crkva Sv. Teodora (Sv. Tudora), crkva Sv. Karla Boromejskog, crkva Sv. Mavra, crkvica Sv. Ivana Krstitelja, crkva Sv. Eufemije (na otočiću Fumija), obiteljska kapelica sv. Antuna, ljetnikovac obitelji Andreis, ljetnikovac obitelji Racetin, ljetnikovac obitelji Paitoni, ljetnikovac obitelji Lucić, Kaštel sv. Ivana. Radić ističe kako je njegova tradicijska arhitektura zaštićena kao spomenik ruralnog graditeljstva, te ga kao takovu treba sačuvati (Radić, 2007:1181).

10 Pretraživanjem baza znanstvenih i stručnih radova, o mjestu Okrug pronađen je samo jedan članak tj. poglavlje u knjizi iz 2007. Gradovi i općine Republike Hrvatske (pod uredništvom Slavka Šislera) autorice
} 
Za odgovor na pitanje koje su okolnosti pridonijele tome da Okrug Gornji postane naselje visoke gustoće izgrađenosti, važno je uzeti u obzir dijakronijsku perspektivu jer razvoj sekundarnog stanovanja na Okrugu traje već pedesetak godina. Naime, analiza evolucije sekundarnog stanovanja u Okrugu temeljena na intervjuima s povremenim i stalnim stanovnicima (Miletić i sur., 2016) otkrila je da gradnja vikendica na prostoru Okruga počinje krajem 1960-ih godina. ${ }^{11}$ Prve su vikendice građene u zoni uvale Mavarčica (južna strana otoka) koja je u to vrijeme bila odvojena od središnjeg naselja i nije imala nikakvu infrastrukturu (pristupne ceste, vodu, električnu energiju). Prva zemljišta kupovale su visokoobrazovane osobe, uglavnom liječnici iz Splita, koje nisu bili zavičajno povezane sa Čiovom nego ih je u Okrug privukao krajobraz iznimne ljepote. I 1970-ih nastavlja se postepeno širenje sekundarnog stanovanja u Okrugu kada tadašnji pripadnici društvene elite, u prvom redu oficiri federalne vojske te rukovodioci društvenih poduzeća, počinju kupovati zemljišta i graditi vikendice. Pritom dolazi do premještanja gradnje i u druge zone, sada bliže središnjem naselju. No, značajan porast izgradnje započinje 1980-ih kada stanovi za odmor postaju dostupni i prosječnom kućanstvu, a broj stanova za odmor u Okrugu je u samo deset godina (1981.-1991.) porastao s 446 na 1722. Tijekom 1990ih godina dolazi do zaustavljanja širenja sekundarnog stanovanja. Veliki dio stanova za odmor mijenja vlasnika, a neki i namjenu. Naime, u to vrijeme doseljava se veliki broj izbjeglica iz središnje Bosne i Hercegovine kao i prognanika iz Kijeva i Vukovara koji kroz kupovinu ili zamjenu s državljanima drugih republika bivše Jugoslavije postaju novi vlasnici vikendica. Prema informacijama prikupljenima od sugovornika (tijekom intervjua), među izbjeglicama prevladavaju Hrvati koji s vremenom odlaze na privremeni rad u Njemačku i Austriju, a nakon stjecanja kapitala kupuju nekretnine u Okrugu te pozivaju svoju rodbinu i prijatelje iz zavičaja koji uz stambeni prostor grade i objekte za iznajmljivanje. Lančano širenje jedan je od snažnijih čimbenika intenziviranja gradnje u Okrugu u prvim godina 21. stoljeća. U tom razdoblju dolazi do adaptacije i dogradnje velikog broja postojećih stambenih objekata, a popisni podaci otkrivaju da je samo između 2001. i 2011. registrirano oko 1000 novih stanova namijenjenih za obavljanje djelatnosti. Riječ je o objektima koji su najčešće korišteni za iznajmljivanje smještaja, što upućuje na značaj turizma za gospodarski razvoj Okruga. Najintenzivniji porast gradnje bio je u razdoblju 2003.-2008. pri čemu su, prema saznanjima dobivenim kroz spomenute intervjue, veliku ulogu imale banke koje su omogućavale lakše dobivanje kredita. Grade

Danke Radić, pod naslovom Općina Okrug. Autorica ukratko opisuje povijest, kulturnu baštinu (spomenike, crkve, kapelice, ljetnikovce i kaštele) razvoj školstva, kulturu i sport te gospodarstvo općine Okrug. 11 Spomenuti intervjui provedeni su u jesen 2015. godine kao prva faza empirijskog istraživanja o sekundarnom stanovanju u Okrugu. Korištena je tehnika polustrukturiranih intervjua, a intervjuirali smo ukupno 15 stalnih i povremenih stanovnika. Izbor ispitanika vršen je metodom grude snijega pri čemu smo u prvom koraku ciljano tražili osobe za koje smo, s obzirom na njihovu ulogu u lokalnoj zajednici, očekivali da bolje poznaju problematiku evolucije sekundarnog stanovanja u Okrugu te stanje i perspektive lokalnog razvoja. Te su spoznaje prezentirane na međunardonoj konferenciji Mediterranean Islands u rujnu 2016. a nisu objavljene dosad kao čalanak, pa se navedena referenca odnosi na sažetak iz knjige sažetaka (Miletić i sur., 2016). 
podjednako doseljenici i domaći, ali i stranci koji su značajnije prisutni od 2005. čemu svakako pridonosi blizina aerodroma ${ }^{12}$. Iako se u početku nekretnine kupuju ili grade za vlastite potrebe, bilo za odmor ili stalno stanovanje, taj se trend ubrzano mijenja i prilika za zaradu postaje snažan čimbenik rasta gradnje, prvo zbog turizma, a onda i poslovanja s nekretninama. U razdoblju 2001.-2011. ukupni stambeni fond općine povećan je 2,2 puta pri čemu je broj stanova za odmor porastao s 1377 na 2047. Od 2010. intenzitet se gradnje smanjuje, prvenstveno zbog velikog broja neprodanih nekretnina, iako se gradi i dalje u manjem obimu. $S$ druge strane, broj se turističkih dolazaka povećava iz godine u godinu pa je tako u 2015. bilo oko 640.000 registriranih noćenja, a ukupni broj raspoloživih ležajeva sugerira da tijekom ljetnih mjeseci u Okrugu boravi i više od 20.000 turista (Ostroški, 2016).

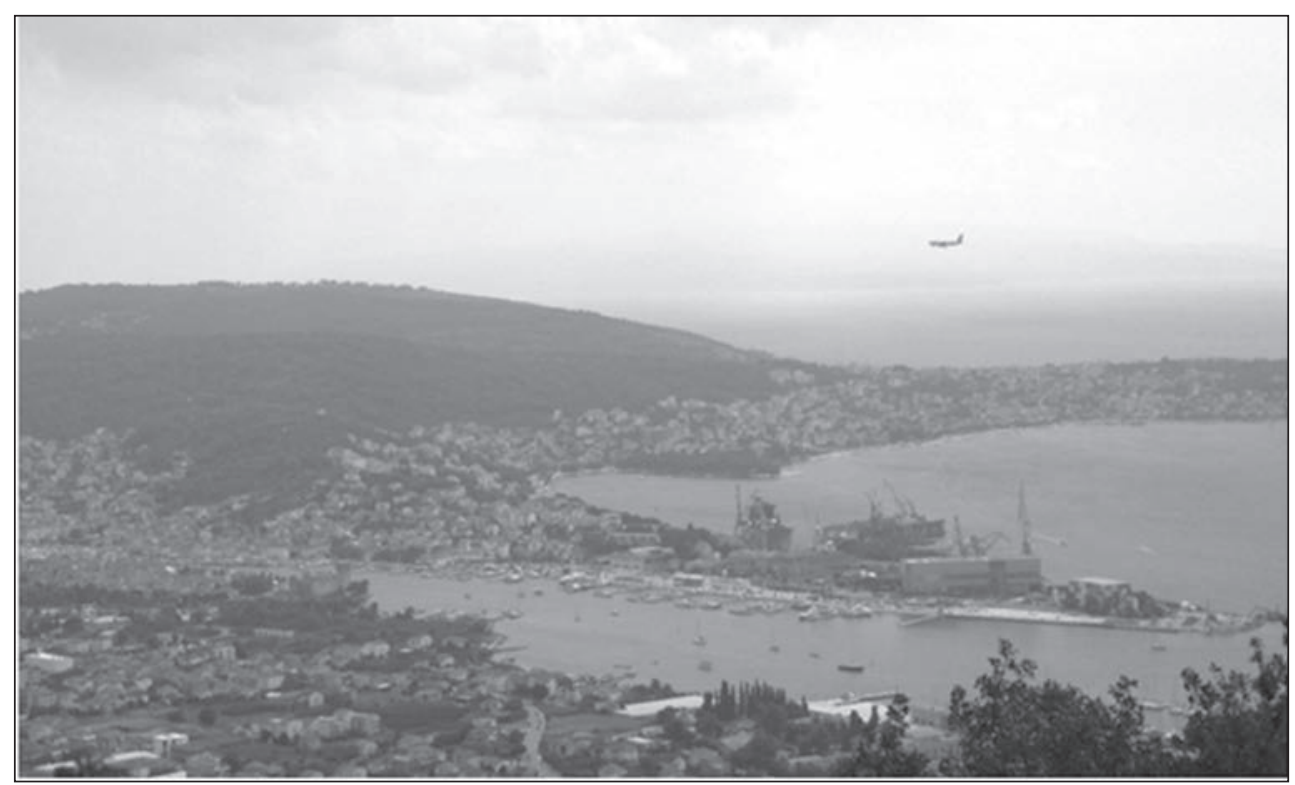

\section{Slika 1. Pogled na Čiovo i Okrug Gornji}

Uz ovako veliki broj posjetitelja povezani su i česti problemi u opskrbi električnom energijom i u opskrbi vodom kao i redovite prometne gužve. Uzrok je tome velika gustoća gradnje koju nije pratila izgradnja adekvatne infrastrukture što uočava i Općinsko vijeće u svom Programu mjera za unapredenje stanja u prostoru općine Okrug (2007.). Glavno je obilježje korištenja prostora koncentracija stambenih i turističkih objekata koji zauzimaju najveći dio Općine uz nisku razinu urbaniteta, vidljivog u deficitu urbanih sadržaja, komunalne i urbane opreme uz neadekvatnu prometnu mrežu i manjak javnih površina te prevladavanje obilježja predgrađa. Navedeni opis stanja u prostoru općine

12 Riječ je o zračnoj luci Split, koja se nalazi se na predjelu Resnik zapadno od Kaštel Štafilića, udaljena 6 $\mathrm{km}$ od Trogira, odnosno $10 \mathrm{~km}$ od Okruga. 
Okrug otvara mnoga pitanja od kojih je u fokusu našega istraživačkog interesa pitanje o razlozima posjedovanja stana za odmor u naselju koje karakterizira visoka gustoća izgrađenosti.

\section{EMPIRIJSKO ISTRAŽIVANJE: ZAŠTO LJUDI IZABIRU OKRUG KAO MJESTO SEKUNDARNOG STANOVANJA?}

\subsection{Ciljevi i metodologija istraživanja}

Kao što je navedeno, glavni cilj empirijskog dijela rada je istražiti koje okolnosti odnosno specifični motivi (grupirani kroz dva glavna indikatora: prirodne ugodnosti i situacijske okolnosti) prevladavaju pri odabira Okruga te u kojoj su mjeri utjecali na odabir ove lokacije za gradnju ili kupnju sekundarnog stana. Također će biti prikazani i podaci o osnovnim obilježjima sekundarnog stanovanja kao i neka obilježja vikendaša u Okrugu koji u analizi predstavljaju nezavisne varijable.

$\mathrm{U}$ analizi će biti korišteni podaci prikupljeni anketnim istraživanjem provedenim u Okrugu Gornjem. ${ }^{13}$

Tablica 1. Osnovna demografska i socioekonomska obilježja uzorka

\begin{tabular}{|c|c|c|}
\hline Varijabla & Kategorija & $\%$ \\
\hline \multirow{2}{*}{ Spol } & Muškarci & 53,3 \\
\hline & Žene & 46,7 \\
\hline \multirow{3}{*}{ Dob } & $18-39$ & 10,0 \\
\hline & $40-64$ & 64,6 \\
\hline & 65 i više & 25,4 \\
\hline \multirow{5}{*}{$\begin{array}{l}\text { Prosječna mjesečna primanja po članu } \\
\text { kućanstva }\end{array}$} & Manje od $2.000 \mathrm{kn}$ & 1,6 \\
\hline & $2.000-4.000 \mathrm{kn}$ & 59,2 \\
\hline & $4.001-6.000 \mathrm{kn}$ & 22,3 \\
\hline & $6.001-8.000 \mathrm{kn}$ & 7,1 \\
\hline & Više od 8.000 kn & 9,8 \\
\hline \multirow{3}{*}{ Obrazovanje } & Osnovna škola & 3,8 \\
\hline & Srednja škola & 66,0 \\
\hline & Visoko obrazovanje & 30,1 \\
\hline
\end{tabular}

13 Pripremajući anketno istraživanje proveli smo seriju intervjua na nekoliko lokacija u kojima smo se detaljno dotakli i pitanja čimbenika odabira lokacije sekundarnog stanovanja (naznačeno u fusnoti 10). Upravo su nam uvidi dobiveni kroz otvorena pitanja u intervjuima poslužili kao okvir za formuliranje zatvorenog pitanja korištenog u anketnom upitniku. 
Istraživanje je provedeno u proljeće i ljeto 2016. godine na probabilističkom višeetapno stratificiranom uzorku mještana i vikendaša. U prvoj etapi, izbor adresa bio je stratificiran po statističkim krugovima. U drugoj i trećoj etapi proveden je slučajan izbor kućanstva (korištenjem tablice slučajnih brojeva) te ispitanika unutar kućanstva (korištenjem metode prvog rođendana). Anketiranje je obavljeno osobno, licem u lice na adresi stana. U ovoj analizi ciljana su populacija povremeni stanovnici. Uzorkom u provedenom istraživanju obuhvaćeno je 211 povremenih stanovnika. U tablici 1. prikazana su osnovna demografska i socio-ekonomska obilježja uzorka vikendaša.

$S$ obzirom na navedene ciljeve empirijskog dijela rada, $\mathrm{u}$ analizi će biti korišteni podaci o obilježjima stana za odmor, konkretno, o načinu stjecanja vikendice, površini stambenog prostora, razdoblju stjecanja vikendice, zavičajnoj povezanosti kućanstva koje koristi vikendicu s Okrugom ili Čiovom, udaljenosti između vikendice i adrese stanovanja, prosječnom broju dana korištenja vikendice te radi li netko iz kućanstva sezonske poslove u Okrugu i iznajmljuju li vikendicu turistima. Osim toga, analizirat ćemo odgovore koji opisuju razloge odabira Okruga kao odredišta sekundarnog stanovanja. Konceptualizacijom su utvrđene dvije osnovne dimenzije odabira lokacije, jedan se odnosi na same prirodne datosti prostora tj. prirodne ugodnosti, a druga na situacijske okolnosti zbog kojih neko mjesto može osobama u kućanstvu biti pogodnije za sekundarno stanovanje. Svaka od navedene dvije dimenzije operacionalizirana je kroz šest varijabli, a ispitanici su pojedinačno ocjenjivali njihov utjecaj na odabir Okruga kao odredišta sekundarnog stanovanja. Ocjena utjecaja mjerena je na skali od pet stupnjeva: uopće ne (1), malo (2), donekle (3), prilično (4) i izrazito (5).

Tablica 2. Razlozi koji opisuju dvije mjerene dimenzije (prirodne ugodnosti i situacijske okolnosti) odabira Okruga kao odredišta sekundarnog stanovanja

\begin{tabular}{|c|c|}
\hline Dimenzija & Varijabla \\
\hline \multirow{6}{*}{ Prirodne ugodnosti } & čisto more \\
\hline & mnoštvo zelenila i šuma \\
\hline & nezagađeni okoliš \\
\hline & blizina plaža \\
\hline & ljepota prirodnog krajolika \\
\hline & povoljna klima \\
\hline \multirow{6}{*}{ Situacijske okolnosti } & sređeni imovinsko-pravni odnosi i sigurnost kupnje \\
\hline & blizina stalne adrese stanovanja \\
\hline & povoljna cijena nekretnine / zemljišta \\
\hline & podrijetlo (osobno ili člana kućanstva) iz ovoga kraja \\
\hline & preporuka prijatelja \\
\hline & očekivani porast cijena nekretnine \\
\hline
\end{tabular}




\subsection{Anketno istraživanje: rezultati i interpretacija}

\subsubsection{Osnovna obilježja sekundarnog stanovanja u Okrugu}

Osnovna obilježja sekundarnog stanovanja u Okrugu prikazana su u tablici 3 . U istraživanjem obuhvaćenom uzorku najviše je bilo kućanstva koja su vikendicu gradila u vlastitom aranžmanu, njih 47,4\%, dok je 34\% kućanstva vikendicu kupilo, a 18,7\% je vikendicu naslijedilo. $S$ obzirom na veličinu vikendica, podaci otkrivaju da dominiraju one srednje veličine. Među anketiranim kućanstvima njih 20,7\% ima vikendicu s površinom do 100 $\mathrm{m}^{2}$, nadalje 46,1\% ima vikendicu površine između 101 i $200 \mathrm{~m}^{2}$, dok njih oko jedne trećine ima vikendice čija površina prelazi $300 \mathrm{~m}^{2}$. Razdioba odgovora na pitanje o godini stjecanja vikendice pokazuje da je u Okrugu vikendicu do 1980. godine steklo 16,8\% anketiranih kućanstava, zatim njih 18,8\% je vikendicu steklo u 1980ima, dok je relativno najveći udio kućanstava, 33,7\%, vikendicu u Okrugu steklo 1990-ih godina prošlog stoljeća (pretežito nakon završetka Domovinskog rata), a uz to znatan je udio kućanstava $30,8 \%$ koja su vikendicu stekli u razdoblju od 2001. do 2016. godine. Obnova zavičajnosti ili pak održavanje veze $s$ mjestom porijekla nešto je što se može povezati s manjim brojem anketiranih kućanstava. Naime, osobna zavičajna povezanost ili zavičajna povezanost nekog člana kućanstva s Okrugom ili Čiovom prisutna je kod 27,6\% kućanstava, dok ostala kućanstva, dakle, velika većina nema rodbinskih veza s tim krajem. Analiza udaljenosti između vikendice i stalne adrese stanovanja otkriva da gotovo polovina anketiranih kućanstava vikendicu ima na udaljenosti do 50 kilometara od stalne adrese stanovanja, njih 19,8\% na udaljenosti između 50 i 400 kilometara dok 30,4\% stalnu adresu stanovanja imaju udaljenu 400 i više kilometara od Okruga. Udaljenost između prve i druge adrese reflektira se i na dinamiku korištenja što potvrđuju prikazani rezultati prema kojima veliki broj kućanstava koristi vikendice i izvan ljetne sezone. Vidljivo je to iz podataka da 34\% kućanstava prosječno koristi vikendice između 91 i 120 dana u godini, a njih $28,6 \%$ čak i više od 121 dana; do 60 dana vikendice koristi 19,7\% kućanstava, a između 61 i 90 dana njih još $17,7 \%$. Anketni rezultati upućuju na to da je kod dijela kućanstava sekundarno stanovanje prilika za stvaranje dodatnih prihoda za kućni budžet; kod 27,6\% kućanstava koja imaju vikendicu u Okrugu barem jedan član radi sezonske poslove, a njih $38,8 \%$ kazalo je da vikendicu ponekad iznajmljuju.

Tablica 3. Osnovna obilježja sekundarnog stanovanja u Okrugu

\begin{tabular}{|l|c|c|}
\hline \multicolumn{1}{|c|}{ Varijabla } & Kategorija & $\%$ \\
\hline \multirow{2}{*}{$\begin{array}{l}\text { Način stjecanja vikendice: objekt koji koristimo kao } \\
\text { vikendicu smo... }\end{array}$} & sami gradili. & 47,4 \\
\cline { 2 - 3 } & kupili. & 34,0 \\
\cline { 2 - 3 } & naslijedili. & 18,7 \\
\hline \multirow{4}{*}{ Površina vikendice $\left(\mathrm{m}^{2}\right)$} & -100 & 20,7 \\
\cline { 2 - 3 } & $101-200$ & 46,1 \\
\cline { 2 - 3 } & $201-300$ & 19,7 \\
\cline { 2 - 3 } & 301 i više & 13,5 \\
\hline
\end{tabular}




\begin{tabular}{|c|c|c|}
\hline \multirow{4}{*}{ Razdoblje stjecanja vikendice } & -1980. & 16,8 \\
\hline & 1981.-1990. & 18,8 \\
\hline & $1991 .-2000$. & 33,7 \\
\hline & 2001.-2016. & 30,8 \\
\hline \multirow{2}{*}{$\begin{array}{l}\text { Zavičajna povezanost kućanstva koje koristi } \\
\text { vikendicu s Okrugom ili Čiovom }\end{array}$} & $\mathrm{Da}$ & 27,6 \\
\hline & $\mathrm{Ne}$ & 72,4 \\
\hline \multirow{3}{*}{$\begin{array}{l}\text { Udaljenost između vikendice i adrese stanovanja } \\
(\mathrm{km})\end{array}$} & $1-50$ & 49,8 \\
\hline & $51-400$ & 19,8 \\
\hline & $>400$ & 30,4 \\
\hline \multirow{4}{*}{ Prosječan broj dana korištenja vikendice } & do 60 & 19,7 \\
\hline & $61-90$ & 17,7 \\
\hline & $91-120$ & 34,0 \\
\hline & 121 i više & 28,6 \\
\hline \multirow{2}{*}{ Radi li netko iz kućanstva sezonske poslove u Okrugu } & $\mathrm{Da}$ & 27,6 \\
\hline & $\mathrm{Ne}$ & 72,4 \\
\hline \multirow{2}{*}{ Iznajmljivanje vikendice } & $\mathrm{da}$ & 38,8 \\
\hline & ne & 61,2 \\
\hline
\end{tabular}

\subsubsection{Analiza čimbenika odabira Okruga kao odredišta sekundarnog stanovanja}

Analiza ocjena razloga odabira Okruga kao odredišta sekundarnog stanovanja pokazala je da su toj odluci znatno više pridonijele prirodne ugodnosti u Okrugu nego same situacijske okolnosti. Točnije, razdioba prikazana na slici 2 pokazuje da je svih šest elemenata koji se odnose na prirodne ugodnosti znatno češće označeno kao prilično ili izrazito važan razlog za posjedovanje vikendice u Okrugu od onih elementa koji upućuju na pragmatičnost u odabiru Okruga. Najčešće su kao priličan ili izraziti razlog odabira Okruga označeni povoljna klima $(86,1 \%)$, čisto more $(83,3 \%)$ te blizina plaža $(80,4 \%)$. Zanimljivo je da za ponuđene „pragmatične“ razloge većina ispitanika smatra kako nisu imali veliko značenje pri odabiru Okruga kao odredišta u kojem će imati stan za odmor. Nešto je više ispitanika tek blizinu stalne adrese stanovanja (49,3\%) te sređene imovinsko-pravne odnose $(41,2 \%)$ označilo kao prilično ili izrazito utjecajan razlog za odabir Okruga. Povoljna cijena nekretnine ili zemljišta, podrijetlo te očekivani porast cijena nekretnine kao prilično i izrazito važan razlog navodilo je samo oko $23 \%$ ispitanika.

U sljedećem koraku bili smo usredotočeni na utvrđivanje faktorske strukture ponuđenih razloga odabira Okruga kao odredišta sekundarnog stanovanja te smo u tu svrhu proveli analizu glavnih komponenti. $U$ ovoj analizi korištene su vrijednosti koje su ispitanici izvorno atribuirali varijablama, a testiranje unutarnje konzistentnosti tako priređenog instrumenta upućuje na njegovu visoku statističku pouzdanost $(\alpha=0,897)$. Opisanom analizom faktorske strukture uz korištenje rotacije varimax u literaturi se redovito navodi ispred, iako je možda lektorski neispravno izdvojili smo dva faktora sa svojstvenim 
vrijednostima većim od 1. Izdvojeni faktori ukupno objašnjavaju 65,16\% varijance, od toga faktor 1 objašnjava 54,97\%, dok faktor 2 objašnjava $10,26 \%$ varijance.

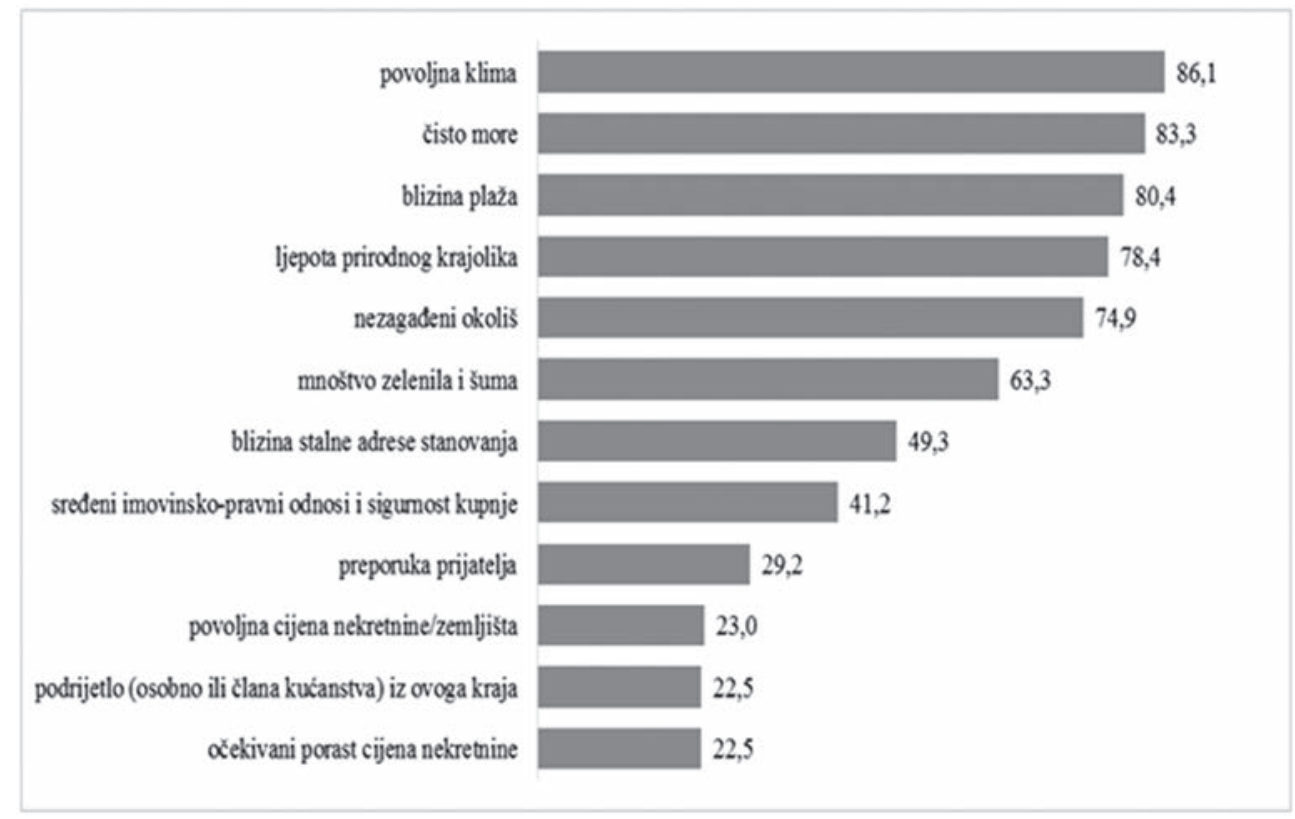

Slika 2. Razlozi odabira Okruga kao odredista sekundarnog stanovanja - udio (\%) odgovora prilično i izrazito

U tablici 4 prikazane su projekcije varijabli s vrijednostima većim od 0,5 na dva izdvojena faktora. Ukupno je devet varijabli imalo veću projekciju na faktoru 1, među njima je svih šest koje se odnose na prirodne ugodnosti (čisto more, mnoštvo zelenila i šuma, nezagađeni okoliš, blizina plaža, ljepota prirodnog krajolika, povoljna klima) te još tri koje se odnose na pragmatične razloge za odabir Okruga kao odredišta sekundarnog stanovanja (sređeni imovinsko-pravni odnosi i sigurnost kupnje, blizina stalne adrese stanovanja, povoljna cijena nekretnine / zemljišta). Analiza korelacija s faktorom 1 pokazuje da varijable koje se odnose na prirodne ugodnosti kao razlog odabira Okruga imaju veću saturaciju od spomenutih varijabli koje se odnose na pragmatične razloge odabira Okruga. Karakter varijabli okupljenih na faktoru 1 sugerira da prirodne ugodnosti jesu dominantan čimbenik pri odabiru Okruga kao odredišta sekundarnog stanovanja. Ipak, kod odluke o lociranju vikendice ispitanici nisu vodili računa isključivo o lijepoj vizuri i obilju prirodnih ugođaja već im je bilo bitno da je ulaganje sigurno, da im vikendica bude na dohvat ruke te da nije skupa.

Na faktoru 2 sljedeće su tri varijable imale projekciju veću od 0,5: podrijetlo (osobno ili člana kućanstva) iz toga kraja, preporuka prijatelja, očekivani porast cijena nekretnine. Riječ je o preostale tri varijable koje se odnose na pragmatične razloge odabira Okruga kao odredišta sekundarnog stanovanja. Dakle, rezultati provedene faktorske analize 
omogućavaju nam dvije neovisne interpretacije: jednu u kojoj je smještanje sekundarnog stana u Okrug u prvom redu rezultat potrage za mjestom koje obiluje prirodnim ugodnostima pri čemu se traži i ispunjenost nekoliko praktičnih (pred)uvjeta; drugu, u kojoj je odabir Okruga rezultat isključivo nekih pragmatičnih razloga.

Tablica 4. Faktorska struktura razloga odabira Okruga kao odredišta sekundarnog stanovanja - matrica ekstrahiranih faktora nakon provedene transformacije varimax ibid.

\begin{tabular}{|l|c|c|}
\hline \multirow{2}{*}{\multicolumn{1}{|c|}{ Varijable }} & \multicolumn{2}{c|}{ Faktori } \\
\cline { 2 - 3 } & 1 & 2 \\
\hline čisto more & 0,883 & \\
\hline mnoštvo zelenila i šuma & 0,829 & \\
\hline nezagađeni okoliš & 0,883 & \\
\hline blizina plaža & 0,887 & \\
\hline ljepota prirodnog krajolika & 0,920 & \\
\hline povoljna klima & 0,876 & \\
\hline sređeni imovinsko-pravni odnosi i sigurnost kupnje & 0,630 & \\
\hline blizina stalne adrese stanovanja & 0,564 & \\
\hline povoljna cijena nekretnine / zemljišta & 0,599 & \\
\hline podrijetlo (osobno ili člana kućanstva) iz ovoga kraja & & 0,755 \\
\hline preporuka prijatelja & & 0,617 \\
\hline očekivani porast cijena nekretnine & & 0,668 \\
\hline
\end{tabular}

\subsubsection{Bivarijatna analiza povezanosti odabira Okruga kao odredišta sekundarnog stanova- nja i pojedinih obilježja sekundarnog stanovanja}

U nastavku smo analizirali povezanost osnovnih obilježja sekundarnog stanovanja s utvrđenom latentnom strukturom razloga odabira Okruga za sekundarno stanovanje. Za izdvojena dva faktora izračunate su prosječne skalne vrijednosti te je za svaki faktor analizirana signifikantnost razlika obzirom na način stjecanja, prosječnu površinu te razdoblje stjecanja sekundarnog stana, i zatim još s obzirom na prosječan broj dana korištenja, radi li netko iz kućanstva sezonske poslove u Okrugu te iznajmljuje li kućanstvo sekundarni stan. Prikazana razdioba u tablici 5 otkriva nekoliko statistički značajnih razlika u ocjeni razloga odabira Okruga kao odredišsta sekundarnog stanovanja. Kod faktora 1, onoga u kojem su razlozi dominantno prirodne ugodnosti Okruga u kombinaciji s nekoliko praktičnih razloga, utvrđena je razlika tek kod dvije varijable: površina vikendice te prosječan broj dana korištenja vikendice. Ispitanici s najvećim vikendicama (površine veće od $300 \mathrm{~m}^{2}$ ) u većoj mjeri su kao razloge odabira Okruga kao odredišta sekundarnog stanovanja isticali varijable okupljene oko faktora 1 . Sezonalnost korištenja vikendice također se pokazala povezanom $s$ analiziranim razlozima odabira Okruga: razlozi odabira Okruga za mjesto sekundarnog stanovanja okupljeni oko faktora 1 nešto su važniji 
ispitanicima čije vikendice se koriste 90 i više dana u godini nego onima u čijim vikendicama se boravi rjeđe od 60 dana.

Kod faktora 2, onoga u kojem najveće projekcije imaju isključivo situacijske okolnosti, utvrđena je razlika s obzirom na način stjecanja vikendice, površinu vikendice te situaciju u kojoj netko iz kućanstva radi sezonski posao u Okrugu. Situacijske okolnosti okupljeni oko faktora 2 češće su bili razlog odabira Okruga za one koji su sami gradili vikendice u usporedbi s onima koji su naslijedili vikendice, zatim za one koje imaju najveće vikendice (veće od $300 \mathrm{~m}^{2}$ ) u usporedbi s onima koji imaju najmanje vikendice $\left(\right.$ do $100 \mathrm{~m}^{2}$ ), kao i za one koji dolaze iz kućanstva u kojima netko radi sezonske poslove u Okrugu.

Tablica 5. Razlike u ocjeni dviju izdvojenih latentnih dimenzija odabira Okruga s obzirom na osnovna obilježja sekundarnog stanovanja

\begin{tabular}{|c|c|c|c|c|c|c|c|c|c|}
\hline \multirow[b]{2}{*}{ Varijabla } & \multirow[b]{2}{*}{ Kategorija } & \multicolumn{4}{|c|}{$\begin{array}{c}\text { Prosječna skalna vrijednost } \\
\text { za faktor } 1 \\
\end{array}$} & \multicolumn{4}{|c|}{$\begin{array}{c}\text { Prosječna skalna vrijednost } \\
\text { za faktor } 2 \\
\end{array}$} \\
\hline & & M & SD & $\begin{array}{l}\text { T-test ili } \\
\text { ANOVA }\end{array}$ & $\begin{array}{l}\text { Post- } \\
\text { hoc } \\
\text { test }\end{array}$ & M & SD & $\begin{array}{l}\text { T-test ili } \\
\text { ANOVA }\end{array}$ & $\begin{array}{l}\text { Post- } \\
\text { hoc } \\
\text { test }\end{array}$ \\
\hline \multirow{3}{*}{$\begin{array}{l}\text { Način stjecanja } \\
\text { vikendice: objekt } \\
\text { koji koristimo } \\
\text { kao vikendicu } \\
\text { smo... }\end{array}$} & sami gradili. & 3,91 & 1,00 & \multirow{3}{*}{2,175} & & 2,36 & 0,84 & \multirow{3}{*}{$4,683^{*}$} & \multirow{3}{*}{$1-3^{*}$} \\
\hline & kupili. & 3,69 & 0,69 & & & 2,67 & 0,88 & & \\
\hline & naslijedili. & 3,59 & 1,06 & & & 2,86 & 1,25 & & \\
\hline \multirow{4}{*}{$\begin{array}{l}\text { Površina } \\
\text { vikendice }\left(\mathrm{m}^{2}\right)\end{array}$} & -100 & 3,53 & 3,53 & \multirow{4}{*}{$4,106^{* *}$} & \multirow{4}{*}{$\begin{array}{c}1-4^{* *} \\
3-4^{*}\end{array}$} & 2,31 & 1,09 & \multirow{4}{*}{$4,037^{* *}$} & \multirow{4}{*}{$1-4^{*}$} \\
\hline & $101-200$ & 3,91 & 3,91 & & & 2,73 & 0,83 & & \\
\hline & $201-300$ & 3,63 & 3,63 & & & 2,46 & 0,89 & & \\
\hline & 301 i više & 4,22 & 4,22 & & & 3,04 & 0,99 & & \\
\hline \multirow{4}{*}{$\begin{array}{l}\text { Razdoblje } \\
\text { stjecanja } \\
\text { vikendice }\end{array}$} & -1980 & 3,66 & 1,30 & \multirow{4}{*}{0,403} & & 2,81 & 1,25 & \multirow{4}{*}{0,963} & \\
\hline & 1981.-1990. & 3,88 & 0,87 & & & 2,52 & 1,12 & & \\
\hline & 1991.-2000. & 3,74 & 0,98 & & & 2,52 & 0,90 & & \\
\hline & 2001.-2016. & 3,82 & 0,65 & & & 2,48 & 0,74 & & \\
\hline \multirow{4}{*}{$\begin{array}{l}\text { Prosječan broj } \\
\text { dana korištenja } \\
\text { vikendice }\end{array}$} & do 60 & 3,39 & 0,94 & \multirow{4}{*}{$4,645^{* *}$} & \multirow{4}{*}{$\begin{array}{l}1-3^{* *} \\
1-4^{* *}\end{array}$} & 2,45 & 0,90 & \multirow{4}{*}{2,547} & \\
\hline & $61-90$ & 3,81 & 0,74 & & & 2,51 & 0,94 & & \\
\hline & $91-120$ & 3,98 & 0,68 & & & 2,46 & 0,85 & & \\
\hline & 121 i više & 3,95 & 0,98 & & & 2,88 & 1,08 & & \\
\hline \multirow{2}{*}{$\begin{array}{l}\text { Radi li netko } \\
\text { iz kućanstva } \\
\text { sezonske poslove }\end{array}$} & $\mathrm{da}$ & 3,99 & 1,07 & \multirow{2}{*}{2,312} & & 3,06 & 1,16 & \multirow{2}{*}{$12,053^{* *}$} & \\
\hline & ne & 3,71 & 1,00 & & & 2,45 & 0,89 & & \\
\hline \multirow{2}{*}{$\begin{array}{l}\text { Iznajmljivanje } \\
\text { vikendice }\end{array}$} & $\mathrm{da}$ & 3,71 & 1,00 & \multirow{2}{*}{0,411} & & 2,60 & 1,10 & \multirow{2}{*}{0,406} & \\
\hline & ne & 3,80 & 0,92 & & & 2,51 & 0,87 & & \\
\hline
\end{tabular}




\section{ZAKLJUČNA RASPRAVA}

Premda mjesto Okrug na otoku Čiovu ne ulazi, primjerice, u konkurenciju ocjenjivanja turističkih destinacija u raznim turističkim patrolama i sl., već osnovni pokazatelji o rastućem broju stanova za odmor kao i npr. o broju turističkih noćenja ukazuju (za razliku od nekih medijskih percepcija o poželjnim destinacijama), na značajan interes i motivaciju upravo za odabir tog mjesta. Za razliku od turista koji se mogu i ne moraju vratiti, vikendaši su to mjesto trajno izabrali kao svoj drugi dom. Već sam osvrt na povijesni razvoj Okruga, podsjeća nas da postoji višestoljetna tradicija odabira Čiova kao ladanjskog prostora tadašnje aristokracije te ukazuje također i na brojne kulturno-povijesne spomenike, koji su nedovoljno pozicionirani i prepoznati kao kulturni proizvodi koji uz prirodna obilježja mogu postati značajan turistički potencijal tog odredišta dajući mu dodanu vrijednost i kroz taj aspekt atraktivnosti prostora.

Unatoč mogućoj apriornoj konstrukciji o turističkoj neatraktivnosti, ali i nepoželjnosti tog mjesta zbog rastuće apartmanizacije i prostorne zagušenosti, ovo je istraživanje prije svega pokazalo da oni koji su Okrug odabrali kao mjesto gdje će kupiti ili graditi kuću ili stan za odmor, ne razmatraju to kao negativne okolnosti koji bi ih mogle demotivirati pri odabiru. Upravo suprotno, kao što i pokazuje ovo istraživanje, tj. analiza rezultata anketnog istraživanja koja je ponudila nekoliko zanimljivih spoznaja. Prvo, ocjene pojedinačnih čimbenika odabira lokacije pokazuju da su prirodne ugodnosti znatno češće od situacijskih okolnosti utjecale na odluku o odabiru Okruga Gornjeg za mjesto sekundarnog stanovanja. Povoljna klima, čisto more, blizina plaže, to su tri najvažnija čimbenika, dok su kao tri najmanje važna čimbenika označeni povoljna cijena nekretnine / zemljišta, zavičajna povezanost te očekivani porast cijena nekretnine. Pritom o iznimnoj važnosti prirodnih ugodnosti za odabir Okruga Gornjeg više od navedenih rangova govori razlika u udjelu; da su kod odluke prva tri čimbenika prilično ili izrazito bila važna kazalo je preko $80 \%$ anketiranih, dok je manje od $25 \%$ ispitanika druga tri označila kao prilično ili izrazito važna za tu odluku.

Drugo, iako su prirodne ugodnosti označene kao dominantan čimbenik odabira Okruga za mjesto sekundarnog stanovanja, faktorska analiza upućuje na to da su oni ipak u dobroj mjeri isprepleteni i s nekim situacijskim okolnostima. Naime, faktorskom analizom su izdvojena dva faktora. U prvom faktoru, koji objašnjava i najveći dio varijance, okupljene su sve čestice koje se odnose na prirodne ugodnosti te još tri koje se odnose na situacijske okolnosti (sređeni imovinsko-pravni odnosi i sigurnost kupnje, blizina stalne adrese stanovanja, povoljna cijena nekretnine / zemljišta). Drugi faktor okupio je preostale tri čestice koje se odnose na neke situacijske okolnosti (podrijetlo iz tog kraja, preporuka prijatelja ili očekivani porast cijena nekretnine). Navedena razdioba otkriva da je dio sekundarnih stanova u Okrugu Gornjem smješten isključivo iz pragmatičnih razloga ali prije svega upućuju na višedimenzionalnost fenomena odabira lokacije stana za odmor. Tako nešto i nije neuobičajeno jer gotovo svaka odluka o kupovini rezultat je određenog kompromisa (Miletić i Mišetić, 2006). Pritom, naša analiza sugerira da lociranje sekundarnog stanovanja, bez obzira što je riječ o praksi koja je u jednom svom 
dijelu odraz bijega od svakodnevice, nije vođeno isključivo željom nego su bitne i mogućnosti. Konkretno, osim same ugodnosti koje mjesto nudi, prilikom odabira Okruga Gornjeg naši su ispitanici vodili računa i o sigurnosti te o troškovima kupnje kao i o tome da im stan za odmor ne bude predaleko od stalne adrese stanovanja.

Treće, analiza povezanosti izdvojenih faktora s odabranim obilježjima sekundarnog stanovanja otkrila je određene statistički značajne razlike. Razlozi okupljeni oko faktora 1, a u kojima smo vidjeli da prevladavaju prirodne ugodnosti, bili su važniji ispitanicima $s$ raskošnijim vikendicama te ispitanicima čija kućanstva vikendice često koriste i izvan ljetne sezone. Do sličnih su nalaza došli i Hall i Muller (2004) čiji su rezultati pokazali da odabir lokacije više ovisi o razini ugodnosti koju neka lokacija nudi kao i o troškovima stjecanja i održavanja nekretnine sekundarnog stana nego o vremenu putovanja između prve i druge adrese. Situacijske okolnosti (varijable okupljene oko faktora 2) kao razloge odabira Okruga za mjesto sekundarnog stanovanja pokazale su se važnijima ispitanicima koji su naslijedili vikendicu, zatim ispitanicima s raskošnijim vikendicama te onima koji dolaze iz kućanstva u kojima netko radi sezonske poslove u Okrugu. Prema tome, situacijske okolnosti postaju čimbenik odabira Okruga više kod onih koji su obiteljski i zavičajno povezani, a takva povezanost se pokazala i u rezultatima kod nekih drugih istraživanjima (npr. Jaakson, 1986; Muller, 2004; Rogić, 1990).

Možemo na kraju reći da se u nedostatku adekvatnijih, Opačićev model od kojeg se inicijalno krenulo, a koji sadrži dvije navedene skupine faktora privlačnosti za odabir lokacije sekundarnog stanovanja, pokazao pogodnim kao teorijsko polazište za empirijsko istraživanje, uz određenu modifikaciju odnosno kroz operacionalizaciju u dva indikatora, koja smo doradili tj. dopunili uvažavajući specifičnosti lokacije i spoznaje dobivene u prethodnom kvalitativnom istraživanju. Primjena i proširenje tog modela kroz korišsteni instrumentarij, mogu poslužiti i kao znanstveni doprinos za buduća empirijska istraživanja o sekundarnom stanovanju. Osim prikazanih spoznaja vezanih za odabir Okruga, možemo uvidjeti kako iskustvo sekundarnog stanovanja iz perspektive samih korisnika nipošto nije homogeni fenomen čak niti na razini jedne lokacije, jer su različite okolnosti utjecale na strukturu samih korisnika, motivaciju za odabir i percepciju mjesta te u konačnici njihovo iskustvo. Međutim, ovo istraživanje ima ograničenje za moguću generalizaciju istraživane pojave prije svega zbog samog uzorka te samo jedne lokacije na kojoj je provedeno. Stoga je ovaj rad o odabiru naselja Okrug Gornji na otoku Čiovu tek jedan od priloga analizi čimbenika odabira mjesta sekundarnog stanovanja i eventualno može poslužiti kao polazišna osnova za buduća istraživanja te tematike, a za jednu širu sliku potrebno je uključiti više lokacija uz komparativnu analizu rezultata. 


\section{LITERATURA}

Andreis, P. (1977). Povijest grada Trogira. Split: Čakavski sabor.

Barke, M. (2008). Second homes in the Spanish housing market: One market or two? Journal of Housing and the Built Environment, 23(4): 277-295.

Chaplin, D. (1999). Consuming work / productive leisure: the consumption patterns of second home environments. Leisure Studies, 18(1): 41-55.

Coppock, J. T. (1977). Second Homes in Perspective. U: Coppock. J. T. (ur.), Second Homes: Curse or Blessing? (str. 1-15). Oxford: Pergamon.

Čaldarović, O. (1989). Društvena dioba prostora. Zagreb: Sociološko društvo Hrvatske.

Državni zavod za statistiku (2011). Popis stanovništva, kućanstava i stanova 2011. godine: stanovi prema načinu korištenja po gradovima / općinama. URL: www.dzs. hr (05.12.2017).

Državni zavod za statistiku (2001). Popis stanovništva, kućanstava i stanova 2001. godine: stanovi prema načinu korištenja po gradovima / općinama. URL: www.dzs. hr (05.12.2017.)

Hall, C. M. i Müller, D. K. (ur.) (2004). Tourism, Mobility and Second Homes - Between Elite Landscape and Common Ground. Clevedon: Channel View Publications.

Halfacree, K. (2011). A solid partner in a fluid world and / or "line of flight"? Interpreting second homes in the era of mobilities. Norsk Geografisk Tidsskrift - Norwegian Journal of Geography, 65(3): 144-153.

Halfacree, K. (2012). Heterolocal Identities? Counter-Urbanisation, Second Homes, and Rural Consumption in the Era of Mobilities. Population, Space and Place, 18(2): 209-224.

Huijbens, E. H. (2012). Sustaining a Village's Social Fabric? Sociologia Ruralis, 52(3): 332- 352.

Jaakson, R. (1986). Second-home domestic tourism. Annals of Tourism Research, 13(3): 367- 391.

Kaltenborn, B. P. (1998.), The Alternate Home - Motives of Recreation Home Use. Norsk Geografisk Tidsskrift - Norwegian Journal of Geography, 52(3): 121-134.

Miletić, G. M., Bara, M. i Marinović Golubić, M. (2016). Second Homes and Transformation of an Island settlement: Case Study from Okrug, Island of Čiovo, Croatia. U: Kaliterna Lipovčan, Lj., Medić, R. i Ramljak, O. (ur.), Book of Abstracts: "Mediterranean Island Conference" (str. 74-74). Zagreb: Institut društvenih znanosti Ivo Pilar i VERN.

Miletić, G. M. (2011). U potrazi za drugim prostorom: sociologijski aspekti sekundarnog stanovanja u Hrvatskoj. Zagreb: Institut društvenih znanosti Ivo Pilar.

Miletić, G. M. i Mišetić, A. (2006). Zašto imati drugu kuću? Analiza motivacije na primjeru vlasnika kuća za odmor na hrvatskoj obali. U: I. Rogić, A. Mišetić, i R. Zimmermann (ur.), Kuća pokraj mora: povremeno stanovanje na Hrvatskoj obali (str. 269-287). Zagreb: Institut društvenih znanosti Ivo Pilar. 
Mišetić, A. (2006). Stavovi mladih o povremenom stanovanju. U: Rogić, I., Mišetić, A. i Zimmermann, R. (ur.), Kuća pokraj mora: povremeno stanovanje na hrvatskoj obali (str. 323-338). Zagreb: Institut društvenih znanosti Ivo Pilar.

Norris, M. i Winston, N. (2010). Second-Home Owners: Escaping, Investing or Retiring?, Tourism Geographies: An International Journal of Tourism Space, Place and Environment, 12(4): 546-567.

Opačić, V. T. (2011). Prijedlog koncepta istraživanja vikendaštva u receptivnome vikendaškom području. Hrvatski geografski glasnik, 73(1): 181-200.

Ostroški, Lj. (2016) Turizam u 2015: Statistička izvješća - Tourism, 2015: Statistical reports. Zagreb: Državni zavod za statstiku.

Pitkänen, K. (2008). Second-home Landscape: The Meaning(s) of Landscape for Second- home Tourism in Finnish Lakeland. Tourism Geographies, 10(2): 169-192.

Paris, C. (2009). Re-positioning Second Homes within Housing Studies: Household Investment, Gentrification, Multiple Residence, Mobility and Hyper-consumption. Housing, Theory and Society, 26(4): 292-310.

Rogić, I. (1990). Stanovati i biti: rasprave iz sociologije stanovanja. Zagreb: Sociološko društvo Hrvatske.

Rogić, I. (2006). Odnos spram kuća za odmor u Hrvatskoj u strategiji urbanizacije 1945.- 2005. U: Rogić, I., Mišetić, A. i Zimmermann, R. (ur.), Kuća pokraj mora: povremeno stanovanje na hrvatskoj obali (str. 93-118). Zagreb: Institut društvenih znanosti Ivo Pilar.

Radić, D. (2007). Općina Okrug. U: Šisler, S. (ur.), Gradovi i općine Republike Hrvatske (str. 1179-1183). Zagreb: Mato Lovrak.

Quinn, B. (2004). Dwelling Through Multiple Places: a Case Study of Second Home Ownership in Ireland. U: Hall, C. M. i Müller, D. K. (ur.), Tourism, Mobility and Second Homes - Between Elite Landscape and Common Ground (str. 113-130). Clevedon: Channel View Publications. 


\title{
CONTRIBUTION TO THE ANALYSIS OF THE FACTORS INVOLVED IN CHOOSING A PLACE OF SECONDARY RESIDENCE: AN EXAMPLE OF THE SETTLEMENT OKRUG GORNJI ON THE ISLAND OF ČIOVO
}

\author{
Krešimir Peračković, Geran-Marko Miletić and Dora Mrčela
}

\begin{abstract}
Summary
The theoretical part of the paper discusses the factors involved in choosing a place of secondary residence. Especially useful is the concept developed by Opacicic, which includes two groups of pull factors: recreational attraction as the basis for choosing the weekend residence, together with other resources. A research instrument was developed by relying on this concept, as well as on the information about local specificities derived from an existing qualitative research in different locations within the settlement Okrug Gornji. The research instrument consisted of two main indicators: natural and situational factors, which were operationalized as variables, and evaluated by the respondents. In the paper, firstly, a brief overview will be given of the development of the settlement Okrug from the time of its rural isolation until its current status as a desirable destination for secondary residence, together with a short overview of the phases of its development as a place of secondary residence. Next, the empirical part of the paper wil explore the motives which drive the choice of this place as a secondary residence. The data on key characteristics of the secondary living in Okrug, as independent variables, will be presented. The analysis will also include the data gathered by conducting a survey in Okrug Gornji in spring and summer 2016 on a probabilistic multi-level stratified sample of the weekenders. The most important results reveal that natural rather than situational factors affect the choice of Okrug Gornji as a place of secondary residence. The three most important natural factors include: mild climate, clean sea and the closeness to the beach, while the three least important factors are: favourable real-estate / land priced, connectedness with the native region, and the expected rise in real-estate prices.
\end{abstract}

Key words: Čiovo, Okrug Gornji, secondary residence, weekenders

\section{EINE BEILAGE ZUR ANALYSE DER FAKTOREN FÜR DIE AUSWAHL DES ORTES FÜR EINE SEKUNDÄRWOHNUNG: BEISPIEL DER SIEDLUNG OKRUG GORNJI AUF DER INSEL ČIOVO}

\author{
Krešimir Peračković, Geran-Marko Miletić und Dora Mrčela
}

\begin{abstract}
Zusammenfassung
In der vorliegendenn Arbeit werden zuerst bestimmte theoretische Ansätze über Faktoren der Auswahl des Ortes für sekundäres Wohnen dargestellt, eines davon, nämlich Opačićs Konzept von zwei Gruppen von Anziehungsfaktoren hat sich als adäquat gezeigt: Die Erholungs- und Anziehungsbasis der rezeptiven Wochenendregion und andere Ressourcen. Von diesem Konzept ausgehend, mit Erkenntnissen über lokale Besonderheiten, zu denen wir durch die vorherige qualitative Forschung in Okrug selbst gekommen sind, wurde ein Forschungsinstrumentarium mit zwei Hauptindikatoren kreiert: Die Annehmlichkeiten der Natur und situative Umstände, die in einigen Variabeln operationalisiert und von Befragten bewertet wurden. Im Kurzen wurde auch die Entwicklung von Okrug von der Zeit der ländlichen Isolierung bis zum heutigen wünschenswerten Reiseziel für sekundäres Wohnen beschrieben, auch Entwicklunhsphasenuz des sekundüren Wohnzieles wurden kurz beschrieben. Das Hauptziel des empirischen Teil der Arbeit ist es, herauszufinden, welche Umstände bzw. spezifische Motive bei der Auswahl von Okrug ausschlaggebend sind und in welchem Ausmaß sie die Auswahl dieses Standortes zum Ort für sekundäres Wohnen beeinflußt haben. Es werden auch Angaben über Grundmerkmale des sekundären Wohnens in Okrug dargestellt, die
\end{abstract}


Soc. ekol. Zagreb, Vol. 27 (2018.), No. 1

Krešimir Peračković et al.: ... Sekundarno stanovanje: naselje Okrug Gornji na otoku Čiovu

in der Analyse zugleich unabhängige Variablen sind. In der Analyse werden auch die Angaben benutzt, die durch eine im Frühling und Sommer 2016 in Okrug Gornji durchgeführten Umfrage an einem in mehreren Etappen probabilistisch stratifizierten Muster von Wochenendurlaubern gesammelt wurden. Unter Ergebnissen sind diejenigen die wichtigsten, die zeigen, dass die Annehmlichkeiten der Natur wesentlich öfter als die situativen Umstände den Entschluß beeinflußt haben, Okrug Gornji zum Ort für das sekundäre Wohnen auszuwählen. Angenehmes Klima, sauberes Meer, Strand in der Nähe sind die drei wichtigsten Faktoren, während als die weniger wichtigen Faktoren günstiger Immobilien / Grundstückspreis, Verbindung mit dem Heimatort oder eine erwartete Steigerung des Immobilienpreises genannt wurden.

Schlüsselwörter: Čiovo, Okrug Gornji, sekundäres Wohnen, Wochenendreisen 